\title{
Development of Cost Analysis Guidance for Indonesian Hospitals
}

\author{
Ragil Setia Dianingati ${ }^{1}$, Arthorn Riewpaiboon ${ }^{2 *}$ \\ 1. Pharmacy Study Program, Faculty of Medicine, Diponegoro University, Semarang, Indonesia \\ 2. Social, Economic, and Administrative Program, Faculty of Pharmacy, Mahidol University, Bangkok, Thailand \\ Submitted: 08-05-2019 Revised:05-07-2019 Accepted: 29-12-2019 \\ Korespondensi : Arthorn Riewpaiboon : Email : arthorn.rie@mahidol.ac.th
}

\begin{abstract}
Health technology assessment is important in the process of national health insurance system development. On the other hand, health technology assessment study needs a cost analysis as a basic, which is a troublesome if there is not any guidance. To help performing the cost analysis study, this study describes the development of a costing manual book and template as a guide for costing analysis in Indonesian hospitals. This management tool developed in stages, from tool drafting, testing in the real life environment, to approval from stakeholders. Costing templates were developed using Microsoft Excel formulas, such as IF, SUMIF and TRANSPOSE. The costing manual book and template were designed for the Indonesian hospital context. The costing template successfully assessed the unit costs of healthcare services in the study hospital. It can calculate the unit costs of healthcare services for 3 main objectives: hospital internal management, reimbursement rate setting and economic evaluation. The costing analysis tool was reviewed and approved by the study hospital staff and stakeholders. Even the model test was only tested in one district hospital, but it was designed to be flexible enough to adapt to different hospital organization structures. The cost analysis guidance is relevant and applicable to district hospitals in Indonesia. It is well accepted by stakeholders and helpful in calculating the hospital unit costs in a practical way. Hopefully, there will be further hospital cost analyses in the future. These cost analyses can then be used as inputs for universal health coverage development.
\end{abstract}

Keywords: cost analysis; costing guidance; Indonesian hospitals

\section{INTRODUCTION}

As the implementation of universal health coverage that has been encouraged by WHO [1], it is critical and essential thing to calculate the full or partial economic evaluation of healthcare services to improve, manage and control the management of hospital services. To calculate the full or partial economic evaluation, a reliable data about hospital cost is needed. Hospital cost covers not only cost, but also resources used to deliver healthcare services to the patients, so that the total cost to treat a patient can be calculated [2]. An accurate and reliable data of hospital cost is also needed to inform the policy maker and the managers to improve the hospital's performance, to allocate the assets and human resources, and to compare the performance with other hospitals [3]. A standardized method of cost analysis should be used to get the data in order to give comparable data within hospitals [4]. Therefore, further calculation needs it to calculate cost of illness, cost of treatment, or even the economic evaluation. There are many choices of approaches and methods that can be used for the calculation. It might lead into different final value of unit cost [5], and it will be difficult to compare each other in order to set the reimbursement rate of provider service that needed for the universal health coverage improvement. Hence, it is important to implement a standardized method for cost analysis.

Moreover, hospitals are important element to provide the health services and consume highest portion of the health sector's budget [3]. Many countries found difficult to establish a cost basis for the rate of various services and packages [6], especially in lowincome countries in Asia. Their existing financial system has not used standard costing method, which found useful [6] and has been applied in many countries and settings.

Indonesia has established its universal health coverage (Jaminan Kesehatan Nasional (JKN) or National Health Insurance Program) in 2014, and plans to achieve the total coverage 
by 2019 [7 8]. Currently, Indonesia is using three systems for the reimbursement rate that according to the healthcare services type. The first ones are capitation and fee for service for the local health center (Puskesmas or Fasilitas Kesehatan Tingkat Pertama (FKTP))[9]. The second one is INA-CBGs (Indonesia Case Based Group) tariff that based on diagnose and procedure of the illness at the Fasilitas Kesehatan Tingkat Lanjutan (FKTL) or the referral health facility, and also non INA CBGs tariff for the healthcare services that not covered by the INA CBGs such as medical devices, chemotherapy, chronic diseases medicines, CAPD and PET Scan [10 11]. Therefore, cost analysis study is needed in order to provide basic information to calculate further studies either full or partial economic evaluation to evaluate the benefit package under the UHC system.

To our knowledge, there is not any report that has been published internationally for the unit cost analysis that follow the costing methodologies that had been established before, such as in Drummond et al., [12]. On the other hand, there is no any guidance or standard in doing cost analysis for hospital healthcare services in Indonesia. A guidance that published by the Ministry of Health is a guide in developing Pharmacoeconomics study that based on a critical appraisal checklist that produced by Deborah Korestein from Department of Medicine, Mount Sinai School of Medicine, Critical Appraisal Skills Programme (CASP), Public Health Resource Unit, Institute of Health Science, Oxford, and also from Drummond et al., "Methods for the Economic Evaluation of Health Care Programmes", that had been translated to Bahasa Indonesia [13].

Meanwhile some hospital cost analysis studies that had been done in Indonesia using different terms in the method comparing to the standard costing method (a review is published elsewhere). There are three costing methods that commonly used in Indonesia based on the reviewed papers [14-20]. The first one is real cost method or traditional costing method, which actually refers to average method in unit cost calculation. Second one is activity based costing, and the last one is double-distribution method, which refers to the indirect cost allocation method. This confusion in costing method that applied in many papers published in Indonesia that reviewed, might be caused by lack of understanding in costing method and there is not any guidance in doing cost analysis especially in hospital healthcare services. Hence it is a necessary thing to align the misunderstood costing methodology and develop a standardized guidance to provide a reliable data for the calculation of full economic analysis.

\section{METHODOLOGY \\ Data collection}

Financial data during June-December 2016 was collected.

\section{Study design}

Study was designed using standard cost approach [21], following the standard six steps in hospital cost analysis. Some reference values are adjustable, depends on the policy of the hospital or government, such as year of analysis, discount rate, useful life of the building and equipment, and number of working day per year. The analysis process is generally divided in to 6 steps as followings: study design; cost center classification; direct cost determination; indirect cost determination; full cost determination; and unit cost calculation. This study was designed as retrospective descriptive cost analysis in July-December 2016. The study population was a district hospital with 45 beds in Yogyakarta. Pratama Yogyakarta hospital was selected by convenience method.

\section{Study procedure}

Financial data was collected with the help from hospital staff in charge. Employee salary, employee working time, resources consumed (electricity, water, etc), hospital assets, each department's output and other crucial data needed for the calculation were obtained from financial record and hospital electronic databases, which called raw data 


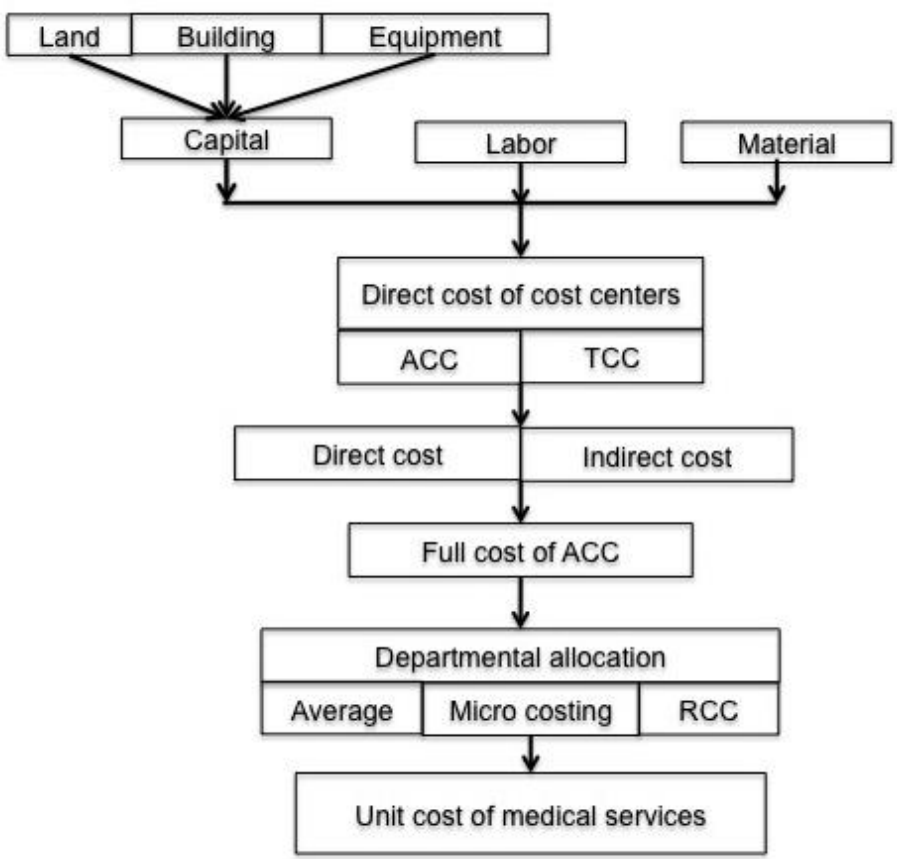

Figure 1. Cost analysis method using standard cost approach

Notes: ACC: Absorbing Cost Centers; TCC: Transient Cost Centers; RCC: Ratio Cost to Charge

later on. Raw data was processed and adjusted until its form match to the cost analysis template. After that, data was inputted to the cost analysis template to see whether the cost analysis template could calculate the unit cost or not. Some adjustment had been done in order to make the cost analysis template works. After that, the final version of the cost analysis template and the result were presented in front of the stakeholders. Review and comments were obtained from the stakeholders and experts after presenting the final output.

\section{Costing template development}

The cost analysis template was designed using Microsoft Excel in order to be user friendly and able to calculate the unit cost of healthcare services using some approaches (economic and financial approach) that could be chosen according to the objective of calculation. Economic approach (opportunity cost) is a measure of the value of resources used or consumed to produce goods or services, while financial approach (accounting) is a measure of cost that based on actual monetary value [21]. Some Excel techniques were employed such as, referencing, cell linkage, SUMIF, IF, VLOOKUP, transpose, and cell protection. Some checking steps were also included to check error step by step. The cost analysis template consists of two Excel files, one for step down approach to calculate the average cost of inpatient and outpatient department and another one for bottom up approach to calculate the unit cost of services in details, followed by the micro-costing allocation for some departments. All cells were cellprotected (except the input cell) to protect the formula. The cost analysis template was designed to calculate unit cost of healthcare services under some circumstances in order to create a costing tool that can fulfill user inquiries. The cost analysis template was designed to be able to calculate by four different objectives, as follows; For hospital internal management using economic 
approach; For hospital internal management using financial approach; For reimbursement rate using financial approach; For economic evaluation using economic approach

\section{Data analysis}

The final version of the cost analysis template and the result of unit cost analysis that calculated using the guidance were presented in front of the stakeholders. Review and comments were obtained from the stakeholders and experts after presenting the final output.

\section{RESULT AND DISCUSSION}

The initial costing template was drafted in order to help hospital managers in doing cost analysis to helm them manage the hospital better. The main result of the study was obtained the costing template and cost analysis guidance for the hospitals, after a few months of gathering data to calculate the unit cost and some modification on the costing template. The costing template was developed to provide a calculation not only to help the hospital managers in doing unit cost calculation, but also to help the policy makers calculating the reimbursement rate setting and the researchers calculating the unit cost for economic evaluation. Some methods and approaches were provided to give more options to the user. The costing template and cost analysis guidance book are able to be downloaded upon request to the author.

After finalized the costing template, the manual book was developed. The manual book consists three parts; a brief knowledge of costing techniques, Excel techniques that had been used in the calculation, and how to calculate unit cost of healthcare services. The first section provides some basic in costing. The detail of explanation in doing cost analysis in general is included. It was developed based on the existing guideline from Newbrander and Lewis (1999), Shepard, Hodgkin and Anthony (2000), and Ozaltin et al., (2014) and followed the standard costing method from Drummond et al., (2005). The second section explains some Excel techniques that employed in the calculation, because not all users may have advanced technique in using Excel. The explanation includes step by step in calculating using Microsoft Excel in Windows and Macintosh based operating software. The third section contains the step-by-step of unit cost calculation with the information about what needs to be inputted and the Excel formula that included in the calculation.

The cost analysis template was developed by the intention to fill in the gap of reliable information in hospital cost data and to support the strengthening of universal health care system in Indonesia. To our knowledge, this is the first cost analysis template and manual book in hospital cost analysis that developed based on the real situation in Indonesia. The study hospital is a type D-government owned hospital, because it is the first tier for patient referral system. The result of unit cost calculation and the costing template were presented to the stakeholders to get some reviews and comments. The costing template seemed to be quite helpful to do a cost analysis, even though the stakeholders have not any experience in doing costing. But it needed some correction due to the error occurred in inputting the data. There were many improvements to be made in order to make it more user-friendly and easier to key in the data.

The initial development of the hospital cost analysis tool was based on a sense to provide a practical cost analysis template to help the hospital managers calculating the cost of giving healthcare services and managing their resources effectively and efficiently. And also the initial cost analysis template was developed based on the costing template that developed by Newbrander and Lewis in 1999, so the initial cost analysis template calculated the unit cost using provider perspective.

After it was tested in the study hospital, the costing template was improved to give broader benefit for its user. The costing template is able to calculate under some methods and approaches according to the objective of the calculation. It also adapted from the data sources from the hospital makes it easier to fill in, since the data is already 
available from the hospital database. It may needs some correction especially in number formatting to be able to be calculated in Excel.

The initial cost analysis template had one workbook that calculates two indirect allocation method, top-down and bottom-up method. But in the process of development, the calculation using top-down and bottom-up was separated in order to make it easier to understand and simplify it, since for each calculation needs dozens of worksheet. If users only want to calculate the average cost of inpatient and outpatient department, they may stop at the top-down calculation, but if they want to calculate other department in details using micro-costing or RCC, they should continue to the bottom-up method. However, the bottom-up method workbook is linked to the top-down method, so the users do not need to fill in the information twice.

The cost analysis template provides some options for the methods employed, in order to calculate under different objectives, which is related to the study design of the hospital cost analysis. User needs to declare the objective of the study clearly on the introduction sheet of the template since the different objective can lead to different result. The following are the objectives that able to be calculated using the template, For hospital internal management using economic approach; For hospital internal management using financial approach; For reimbursement rate using financial approach; For economic evaluation using economic approach.

For internal hospital management, it includes capital, material, and labor cost, and user can choose the approach whether it is financially or economically. For the reimbursement rate setting, the approach that used in this calculation is financial approach and only includes the material cost, since the hospital is government owned and the labor cost is the responsibility of the Ministry of State Affairs. And for the economic evaluation study, it uses economic approach and includes all cost object, including the opportunity cost of the land. The ability to calculate under different objectives and give different result is one of the benefits from using this cost analysis template. It is also possible to modify the objective and include or exclude some cost items due to desirable calculation.

Another benefit from the template is giving some images about hospital cost recovery. A factor that influences unit cost of healthcare services calculation is quantity of the output or services, which is inversely proportional to the unit cost. The higher the output will make the unit cost decreased. If users want to predict how high the output should be to recover the annual hospital cost, they can simply modify the table by dividing the full cost of explored cost center with the reference price of the medical service.

However, besides of its flexibility and benefits, this cost analysis template also has some limitations. Even the cost analysis template is managed to be able to give accurate and reliable data for hospital unit cost, the accuracy of the results depends on the accuracy of the inputted data. After some modifications that made by the user, it is not impossible if there is any malfunction on the calculation. It needs manual checking to the calculation, because the error may be caused by the formula or data inputted. Another limitation of the study was this template was tested at one hospital only, so it might not generalized since Indonesia has many types of hospitals, but the template is able to modified to adapt with the hospitals' situation if the users have enough knowledge of costing and Ms. Excel's skills, which can be gained through workshops.

The variance of costing result that affected from different approach is considerable by the government in setting up the reference price especially for the universal health coverage implementation. The way of capital cost calculation needs to be considered, especially the use of economic approach instead of financial approach. Besides the difference is quite significant, the accounting technique that neglects cost beyond the useful life year is not quite relevant compared to the actual cost in the real life. And also the unit cost result from the study hospital is only a 
demonstrable case in order to test the cost analysis template initially. But in the end, it can be useful to reform the regulation in reimbursement rate setting calculation, since the Indonesia UHC system is facing an increasing deficit annually. Moreover, since this cost analysis template is also based on some assumption, a national reference guidance in useful life year, discount rate and opportunity cost of the land, needs to be set up in order to give clear information to avoid misleading in doing calculation.

Even though the cost analysis template that developed is able to give information in method of unit cost of healthcare services calculation and also unit cost result in the study hospital, this cost analysis template is still based on some assumptions. Based on significant effect that aforementioned, the hospital managers and the government need to be careful in choosing the study design that will affect the method employed. For the private hospital, it may be more useful if they use objective one and include the opportunity cost of the land, while for the government owned hospital is more likely to choose objective 3 , which only includes the material cost, since the labor and capital cost are the governments responsibility.

In order to use the cost analysis template properly, users still need to be trained. Basic knowledge about hospital cost analysis and Excel techniques are compulsory to run the template, especially if the users want to modify the template to meet their objective that is not one of the provided in the template. This limitation is avoided by providing the manual book that contains brief knowledge of costing, Excel techniques that used in the calculation, and how to calculate the cost of healthcare services. Since in Indonesia hospital unit cost is not quite popular, a short workshop and accompaniment until a study has been finished are needed.

One of the efforts to reform the basic cost analysis concept in Indonesia is providing a guidance in cost analysis that directly applicable to Indonesia situation. The developed costing template was developed according to a costing template from Newbrander and Lewis (1999), but it was modified to be suitable with the natural data from the study hospital, in order to make it easier for the users to use it since they already have the data from the hospital database and they just need to input it to the template.

The developed costing template might seem more complicated than the one from Newbrander and Lewis because it has more features, especially in its objectives and approaches. There are two workbooks, one for top-down approach and another one for bottom-up approach. The top-down approach is used if user wants to calculate average cost of inpatient and outpatient department, while the bottom-up approach is used to calculate the average cost of other absorbing cost center, such as pharmacy and catering, or to calculate the unit cost of each service using microcosting method and ratio of cost to charge. According to the manual from Shepard, Hodgkin and Anthony [22] another reason to choose the approach is depending on the purpose of analysis, if the analysis is done to compare the cost of certain hospital departments, unit cost calculation for each service is needed (in this template using the bottom-up approach). But if the analysis is done to compare multiple hospitals with similar case load, user just needs to calculate the average cost of homogenous service (such as inpatient care cost) for each hospital (in this template using the topdown approach).

Comparing to the existed guidance in cost analysis (Newbrander and Lewis; Shepard, Hodgkin and Anthony), the developed cost analysis guidance was designed to be suitable for Indonesian hospital situation that able to be a nationally standardized cost analysis method to calculate the unit cost. It includes the cost analysis template along with the example from the study hospital. However, the cost analysis template may need some adjustment according to the research object, because there are many type of hospital in Indonesia that each other may be slightly different. 


\section{CONCLUSION}

The guidance that comprises a cost analysis template and manual book meets the objective and it is found to be useful for the users according to its simplicity and adjustable features. The guidance fits in the Indonesian hospital condition. The simulation of hospital cost analysis in study hospital found that the unit cost services is multiple times higher than the designated price by the government, since the study hospital is quite new and has less number of patients. However, the accuracy of the result depends on the accuracy of the inputted data and some reference value must be set up by another guidance from the government to give a national standard, such in useful life year, discount rate, opportunity cost of the land, that fruitful to do hospital unit cost calculation.

\section{ACKNOWLEDGEMENTS}

This study had been done by the support from LPDP (Indonesia Endowment Fund for Education). There is no conflict interest between the author and the source of fund.

\section{REFERENCE}

1. WHO. Research for Universal Health Coverage. The world health report 2013. Geneva: WHO, 2013.

2. Independent Hospital Pricing Authority of Australia. Australian Hospital Patient Costing Standards. Australia: Independent Hospital Pricing Authority of Australia, 2018.

3. Newbrander W, Lewis E. Hospital Costing Model Manual: Health Reform and Financing Program \& APHIA Financing and Sustainability Project, Management Sciences for Health, 1999.

4. Mogyorosy Z., Smith P. The main methodological issues in costing health care services: a literature review. University of York: Centre of Health Economics, 2005.

5. Riewpaiboon A., Malaroje S., Kongsawatt S. Effect of costing methods on unit cost of hospital medical services. Tropical medicine \& international health : TM \& IH 2007;12(4):554-63 doi: 10.1111/j.1365-

3156.2007.01815.x[published Online First: Epub Date]l.

6. Ozaltın A., and C. Cashin. Costing of Health Services for Provider Payment: A Practical Manual Based on Country Costing Challenges, Trade-offs and Solutions: Joint Learning Network for Universal Health Coverage, 2014.

7. Clearstate. Universal healthcare coverage in Indonesia-One year on. Indonesia UHC Scheme: The Economist Intelligence Unit, 2015.

8. Marzoeki P., Tandon A., Bi X., Pambudi ES. Indonesia - Universal health coverage for inclusive and sustainable development : country summary report. Washington DC: World Bank Group, 2014.

9. BPJS Kesehatan. Sistem Rujukan Berjenjang (Patient Referral System). Jakarta: BPJS Kesehatan, 2014.

10. Kementerian Kesehatan Republik Indonesia. Petunjuk Teknis Sistem Indonesian Case Base Groups (INACBGs). In: Health Mo, ed. Jakarta: Ministry of Health, 2014.

11. Kementerian Kesehatan Republik Indonesia. Standar Tarif Pelayanan Kesehatan dalam Penyelenggaraan Program Jaminan Kesehatan. In: Health Mo, ed. Jakarta: Ministry of Health, 2016.

12. Drummond MF., Sculpher MJ., Torrance GW., O'Brien BJ., Stoddart GL. Methods for the economic evaluation of health care programmes third edition. Oxford: Oxford University Press., 2005.

13. Kementerian Kesehatan Republik Indonesia. Pedoman Penerapan Kajian Farmakoekonomi. In: Indonesia KKR, ed. Jakarta: Kementerian Kesehatan Republik Indonesia, 2013:72.

14. Eryani L. Analisa Biaya Satuan Pelayanan (Unit Cost) dengan Metode Activity Based Costing (ABC) sebagai Pembanding Jasa Sarana Tarif Pelayanan Endoskopi, Studi pada 
RSUD Kota Yogyakarta. Gadjah Mada University, 2013.

15. Sugiyarti AT., Nuryadi., Sandra C. Unit Cost Analysis (Unit Cost) With Activity Based Costing Method (ABC) (Case Study In Eyes at RSD Balung Jember). Jurnal Pustaka Kesehatan, 2013;1(1)

16. Apriliani VE. Analisis Penentuan Tarif Jasa Rawat Inap Rumah Sakit dengan Menggunakan ABC Sistem. Muhammadiyah Malang University, 2016.

17. Purwanti BM. Analisis Penerapan Penghitungan Unit Cost dengan Metode Double Ditribution pada Unit Radiologi Tahun 2014, Studi Kasus: Rumah Sakit Hana Charitas. Sanata Dharma University, 2016.

18. Puspitasari IF. Analisis Perbandingan Metode Konvensional dengan Metode Activity Based Costing untuk Meningkatkan Akurasi dalam Menentukan Tarif Rawat Inap (Studi
Empiris pada Rumah Sakit Queen Latifa). PGRI Yogyakarta University, 2016.

19. Rahmaniar D. Analisis Biaya Satuan Metode Activity Based Costing (ABC) dalam Evaluasi Tarif Pelayanan Rumah Sakit "X" Surabaya. Airlangga University, 2016.

20. Rahmaniar D., Rochmah TN. Analisis Biaya Satuan Metode Activity Based Costing (Abc) Dalam Evaluasi Tarif Pelayanan Di Klinik Spesialis Bedah Saraf Rumah Sakit " $X$ " Surabaya. Jurnal Manajemen Kesehatan Yayasan RS Dr. Soetomo 2017;3(2):76-87

21. Creese A., Parker D. Cost Analysis in Primary Health Care. Geneva: World Health Organization, 1994.

22. Shepard DS., Hodgkin D, Anthony YE. Analysis of hospital costs: A manual for managers. Geneva: World Health Organization, 2000. 